\title{
The Discourse of Power in Kazou Ishiguro's The Remains of the Day
}

\author{
Hanan Barakat Dweedar \\ Associate Professor of English Literature \\ Department of English Language \& Literature \\ Faculty of Arts, Helwan University \\ hananbarakatd@yahoo.com
}

\begin{abstract}
This study aims to examine power relations in The Remains of the Day (1989) by the Noble laureate Kazuo Ishiguro (1954 -- ). The study draws on T. A. van Dijk theory of Discourse and Power to show how the declining power of the British Empire relates to the emerging American one in the years preceding WWII. Selected encounters between characters of each camp, the English and the American, are analyzed to show how discourse is manipulated to assert domination. The reason for choosing van Dijk's theory is that it "focuses on the ways discourse structures enact, confirm, legitimate, reproduce, or challenge relations of power abuse and dominance in society" (Dijk, 2001 , p. 353). The theory of van Dijk, which handles these diverse issues of how power works, is believed to serve the objective of the present study.
\end{abstract}

\section{Keywords}

Knowledge, power, domination, World War II, English, American, butler.

\section{Introduction}

The Remains of the Day is about an English butler, Stevens, who sets out for Cornwall to recruit Miss Kenton, a former housekeeper. During journeying through the countryside, Stevens reminisces on his service years at Darlington Hall. The novel received Man Booker prize in 1989, and ever since its publication it has been the subject of diverse literary approaches. Among these approaches are Historiographical, Emara (2015); Sloane (2018); philosophic (Marcus 2006); unreliable narration (Horton 2014) and cognitive Text World Theory reading (Whitely 2011). The anti-American sentiment which dominates the novel is often dealt with in these scholarly works.

Shedding more light on Ishiguro's attitude towards America as a superpower is crucial to the present study. The writer's "consistent preoccupation with the 'alarming' Americanisation of world culture" (Sloane, 2018, p. 156) is noted to be echoing in his novels such as A Pale View of Hill 
and An Artist of the Floating World, as well as in his interviews. Ishiguro's critical attitude is reflected in his handling of the issue of the universality of literary works written by American writers. In one of these interviews, Ishiguro argues that American writers have achieved universality simply because they belong to the most powerful country.

I think suddenly, because of historical reasons, British writers who had always thought all they had to do was simply describe British life and they would automatically be writing novels of international appeal, interest, and relevance, suddenly found themselves writing small provincial novels. And, this question about "the way history is moving"--I was suggesting perhaps that even American writers had now got themselves into this position by virtue of the dominance of American culture. That someone who wrote what was essentially an inward looking novel just describing some aspect of American cultural life could almost accidentally--because of the dominant position of America in world society--claim to have written a novel of universal relevance.(Wong, 2008, p. 178)

Ishiguro engages the notion of the evolution of history to justify the universality of American literature. He sees that English writers once enjoyed worldwide readership simply because of the domination of the British Empire, so now it is the turn of American writers to enjoy the same privilege for the same political reason. He denies that American writers, and before them English writers, have produced successful works on their own merits, as such, success is guaranteed for whatever these writers produce, regardless of craftsmanship. He further opines that novels written by writers of powerful countries do not necessarily echo global interests or even share universal human values.

\section{Knowledge and Domination}

The Remains of the Day is a first person narrative; the setting of the novel is Darlington Hall, an English country house where the protagonist begins his reminiscence in July 1956. This particular date marks the Suez Crisis which ended up with the defeat of the United Kingdom and its allies. As such, the novel has been "commonly contextualized ... in light of England's imperial decline and waning world power" (Rich, 2016, p. 501). Further, the narrator's reminisces take the reader back to the years leading up to WWII. This war is also noted by critics as, " represent[ing] the moment of initiation (or 
acceleration) of decline in Britain's (and England's) power in the world, planting the seeds of the dismantling of the empire and Britain's fall into the second strata of nations behind the superpowers of the United States and ... the Soviet Union" (Bentley, 2014, p. 140). Referring to these military crises has a political significance; the novel captures the historical moment when the United Kingdom is on the brink of losing its prestigious global position while America replaces it. In this historical context, British characters work hard to preserve their cultural and political domination over the newly emerging American power.

Knowledge is the main weapon used in the novel, it is used both by English and American characters to assert domination over each other. van Dijk's Critical Discourse Analysis (CDA) deals with the relationship between discourse and power. One of the basic concepts of CDA which contributes to the theoretical framework is "macro vs. micro" (van Dijk, 2001, p. 354) levels of analysis. van Dijk (2001) refers to power and domination practiced by individuals (micro) who belong to and depend on the power of a larger dominant social structure; here we have a small scaled power derived from a larger one. Consequently, CDA bridges the gap between "micro and macro approaches" (van Dijk, 2001, p.354), which in everyday social interactions complement one another. The social power used by dominant groups is defined by van Dijk (2001), "in terms of control" (354). This control could be practiced on the "acts and minds of (members of) other groups" (van Dijk, 2001, p. 355). Dijk (2001) enumerates the privileges of powerful groups as having "access to scarce social resources such as force, money, status, knowledge, information, "culture" ..." (p. 355). Within this framework of social relationships, there exists a kind of division based on access or non-access to one or more of these resources. So, people who have one or more of these resources represent the dominant group and those who don't have represent the dominated. van Dijk (2012) sheds more light on the nature of knowledge.

...knowledge is both cognitive and social. It is cognitive because it is stored, shared and distributed as mental representation in the minds of people (and neurologically coded in their brain). It is social because knowledge is (i) shared and distributed among the members of a community, (ii) acquired and changed (also in) social interaction and discourse (ii) used and applied in social practices, and (iv) institutionally normalized. (p. 154) 
Knowledge is described as both cognitive and social because it is established in the minds, shared and debated by members of a certain epistemic community. So, whatever discourse shared by a certain epistemic community on certain knowledge, usually displays sets of beliefs that comply with this knowledge.

Furthermore, van Dijk relates discourse and knowledge to power, which is almost synonymous with domination. His approach to the relationship between knowledge and domination is described as "more multidisciplinary, inspired by both the cognitive and the social science" (2012, pp. 151-2). van Dijk's discourse theory shows how those who possess knowledge are those who understand their discourse very well. Meanwhile, knowledge "itself is produced and especially reproduced through discourse" (2012, p. 183). Since not everyone possesses this knowledge, as its accessibility is not open to all members of society, knowledge and discourse become "fundamental power resource" (2012, p. 183). Furthermore, in his analysis of the conduct of dominant groups, van Dijk(1993) poses the following question, "If powerful speakers or groups enact or otherwise exhibit their power in discourse, we need to know exactly how this is done. And if they thus are able to persuade or otherwise influence their audiences, we also want to know which discursive structures and strategies are involved in that process" (p. 259). Regarding fictional works, narratologists' opinion on the privilege of first person narrator represents an answer to van Dijk's questions. They see that a first person narrator enjoys the privilege of being "enlightened and knowing narrator who elucidates his mental confusions of earlier days ... [and] can even call on more direct methods for reporting his past consciousness, by verbatim quotation and narration of thoughts that passed through his mind" (Cohn, 1978, pp. 143-4). Such free access to past experience is limited to first person narrators. The other characters are deprived of the same privilege unless they transmit either their past or present consciousness or the two together, to the narrator who, in turn, transmits them to the reader.

Ishiguro's choice of first person point of view for The Remains of the Day also represents an answer to van Dijk's posed questions on the strategies of powerful groups. By being the sole narrator, the English butler has a unique opportunity to be selective in his reminiscence about his service years at Darlington Hall. In an interview with Graham Swift (2008), Ishiguro points out that the protagonist "is intelligent enough, in the true sense of the word, to perceive the danger areas, and this controls how narrative goes" (p.38). The 
author hints at empowering the protagonist by making him the sole narrator, thus he controls the narrative. Ishiguro grants the butler the freedom to choose what to tell and what to suppress, and it is left to the reader to guess the untold. By maintaining the only narrative voice, Stevens becomes a "powerful" speaker; he enacts his power by portraying the relationship with Mr Farraday from his own perspective. Ishiguro's choice of first person point of view for The Remains of the Day is the first sign of Stevens's concealed sense of domination over his American master. The butler, as will be shown later, makes the best of his privileged position as the sole narrator; meanwhile, Ishiguro rarely allows the reader access into Mr Farraday's internal perspective. It can be argued here that in terms of the relationship between America and England, the domination of Stevens's narrating voice signifies an authorial strategy to allow for British retaliation against the American rise to power.

Indeed, the issue of British global domination is often reflected on by Stevens. Although he does not play a direct part in this domination, he harbours the sentiment that he has had his own role to play.

... each of us harboured the desire to make our own small contribution to the creation of a better world, and saw that, as professionals, the surest means of doing so would be to serve the great gentlemen of our times in whose hands civilization had been entrusted. (Ishiguro, 1989, p. 122)

Stevens's sense of glory can be detected in the above passage. He is convinced that that by serving a high profiled statesman who had once taken part in shaping the policy of his country, he, too, had been making his own contribution to civilization. He believes that though his contribution might seem small compared to that of his master, it has delivered its positive effect on the world. The butler is convinced that his contribution, which also occasions his sense of power, has been derived from that of Lord Darlington. He is deeply convinced that by serving a high profile statesman who had once taken part in shaping the policy of his country, he, too, had been making his own contribution to civilization. Stevens's sense of glory is often targeted by critics. Rebecca L. Walkowitz (2015) considers it as "conceit" as he assumes "ethical and political significance" (p. 95) to his action of polishing household silver. Salman Rushdie (2017) further tosses the butler away as "the shadow that speaks" (para. 3). Shedding more light on this issue, Ishiguro explains how ordinary people like Stevens are empowered by this conviction,"[t]he butler is a good metaphor for 
the relationship of very ordinary, small people to power. Most of us aren't given governments to run or coup d'etats to lead. We have to offer up the little services we have perfected to various people: to causes, to employers, to organizations and hope for the best - that we approve of the way it gets used" (Swift, 2008, p. 37).

However, Stevens's sense of glory seems to be tarnished by the selling of Darlington Hall to an American gentleman. Naturally enough, the butler has not taken part in deciding this purchase. Thus, the purchase has created a dilemma to what he "deeply believes that butlers should choose employers who serve lofty public end" (Atkinson, 1995, p. 188). The new employer does not have the glory of his former master, Lord Darlington; he does not take part in shaping human civilization. Indeed, this belief makes Stevens feel reluctant to accept this American employer. At the same time, Stevens considers "Darlington Hall, a house and grounds that constitute ... his world, his country" (Sloane, 2018, p. 168). Stevens's mixed feelings of pride in taking part in shaping civilization on one hand, and on the other, his professional obligations towards an American master are all reflected in his constant remarks over cultural differences between the two countries: England and America.

Stevens's overwhelming concern over the new foreign ownership of Darlington Hall is shown in his continued remarks over the behaviour of his American employer. It is noteworthy that he does not mind being materially dominated by someone; being a butler necessitates being mastered and employed by one master or another. Indeed, it is the origin of the new employer that motivates him to assert his cultural domination, as an English man, over his employer, the American employer.

As mentioned earlier, by being the only narrative voice, Stevens becomes a "powerful" speaker; he enacts his power by portraying the relationship with his new American employer from his own perspective. The reader is not offered the perspective of the actual dominant character, Mr Farraday, rather it is the butler's that dominates the narrative and shapes its course. Hence, his choice of the site of his encounters with his employer is yet another way of demonstrating his domination. Most of these encounters, significantly enough, take place in the library. van Dijk(1993) counts "elements of setting, as the location ... and its prestigious props" (p. 271) as signs of power and authority. So, how these two components of power and domination are enacted in the choice of the library as almost the only location of the encounters between Stevens and Mr Frraday? 
A library is universally acknowledged as providing "access to an endless variety of information resources ... [its] fundamental mission has remained, to facilitate and give ... knowledge" (Holmberg et al., 2009, p. 669). These resources are considered as bases of development; if individuals attain them, they are also empowered. The cultural role of the location, the library, is manipulated by Stevens when he describes his employer's going into the library "carrying a few volumes which he presumably wished returned to the shelves" (Ishiguro, 1989, p. 3). This apparent casual remark is a telling one. The American employer is seen to be returning books to the library, probably after finishing reading them. Needless to say here that, the books in this library had been the purchase of successive generations of the Darlingtons, who built and owned the estate for two centuries. This suggests that this English place, the library, is the source of knowledge for the new American owner. This can be read as a hint to the reader that the new American employer may have owned the money with which he could purchase the English estate, but the source of knowledge in its different fields belongs to England. Besides, Stevens refers to some of the portraits in the library, in particular, he identifies the portrait of "Viscount Wetherby" (Ishiguro, 1989, p. 3), as that which he has been dusting when Mr Farraday enters the library. The portrait of the Viscount has double functions: the first is an artistic one as it signifies that the books are not the only items which the library contains; second, the rank of Viscount both signifies the noble status and the sovereignty of the Darlingtons. Thus, the artistic piece of work adds a cultural and political dimension to the place.

However, the motif of the library is not the only strategy of domination employed by Stevens over his American employer. The butler manipulates the situation when Mr Farrady suggests that he should take a few days off and tour the country. The encounter between Stevens and his employer is represented in a way that alludes to the greatness of England and the prestigious people who contributed to this greatness.

This was not the first time my employer had raised such a question... On this occasion, in fact, a reply of sorts did occur to me as I stood up there on the ladder; a reply to the effect that those of our profession, although we did not see a great deal of the country in the sense of touring the countryside and visiting picturesque sites, did actually 'see' more of England than most, placed as we were in houses where the greatest ladies 
and gentlemen of the land gathered. Of course, I could have expressed this view to Mr Farraday without embarking upon what might have seemed a presumptuous speech. I thus contended myself by saying simply:

'It has been my privilege to see the best of England over the years, sir, within these very walls.' (Ishiguro, 1989, p. 4)

In the above quoted encounter, the physical position of the butler corresponds to the kind of notions he is reflecting upon. The position of Stevens is on top of the ladder, thus he physically occupies a place higher than his American employer. It is also noteworthy that Steven must be looking down from above the ladder on his employer as he engages in this encounter. This is the place where Stevens chooses to locate himself while he briefly reminisces about hosting gatherings of "the greatest ladies and gentlemen of the land." The use of the superlative "the greatest" without specifying the field of the greatness of these people indicates that it is open to all fields: economic, political, scientific, literary, artistic ...etc. This greatness is later specified when he informs the reader that Darlington Hall hosted "[o]ur Prime Minister of that time, Mr Lloyd George" (Ishiguro, 1989, p. 78), "Mr H. G. Wells, the renowned author" (Ishiguro, 1989, p.77), and "Mr John Maynard Keynes" (Ishiguro, 1989, p.77), the great English economist. But in this particular episode, choosing to be unspecific about the areas of the greatness of these guests evokes the age of the Great British Empire. Stevens is well aware that the country of his new employer lacks such well established grandiose; such awareness is implied when he stops short of communicating to Farraday his elevated sentiments of the true grandeur of his former employer's guests. However, this suppression is compensated for by manipulating one of the characteristics of first person narrative situation which is the narrator's ability to take the reader into his confidentiality. Stevens confides to the reader that his thoughts, had they been expressed to the American employer, might have been taken as "presumptuous." $\mathrm{He}$ evokes the genuine greatness of his country as well as that of Lord Darlington, and at the same time insinuates that his new employer lacks both.

Yet, Stevens's implicit message of the superiority of his country over that of his employer is not the only strategy of domination. He employs what van $\operatorname{Dijk}(1993)$ terms as "positive self- presentation and negative otherpresentation" (p. 264). It is a strategy seen by van Dijk as seeking to deliver the effect of marginalizing the rival group. He points out that, "[d]epending on the 
targets of such discursive marginalization of dominated groups, we may thus generally expect the structures and strategies of dominant talk to focus on various forms of positive self-presentation and negative otherpresentation"(p.264). In his division of the rival parties into two, the dominant and the dominated, van Dijk explores a further strategy to emphasize the position of the dominant. It is how the powerful party represents itself to the less powerful one; in this situation, the sort of representation both of the self and the other is a key strategy. Stevens makes use of this strategy when he evokes the issue of his American employer's 'bantering'. He offers an example of this bantering as he suggests to Mr Farraday re-recruiting Miss Kenton, the former housekeeper.

'My, my, Stevens. A lady-friend. And at your age.'

This was a most embarrassing situation, one in which Lord Darlington would never have placed an employee. But then I do not mean to imply anything derogatory about Mr Farraday; he is, after all, an American gentleman and his ways are often very different. There is no question at all that he meant any harm; but you will no doubt appreciate how uncomfortable a situation this was for me. (Ishiguro, 1989, p. 14)

In the above passage, Mr Farraday's remark is friendly and suggests an atmosphere of ease. Yet, Stevens is neither used to nor pleased with his employer's words. The informality of Mr Farraday's bantering suggests a disruption of English codes of the master-butler relationship. By the standards of English butlers "the idea of inappropriate informality would have seemed impolite and alien" (Bruce, 1980, p. 8). Further, according to these codes, $\mathrm{Mr}$ Farraday's familiarity "breeds contempt in the long run" (Ferry, 2001, p. 13). So, if Mr Farraday's bantering suggests a sense of familiarity, sure it violates the measure of decorum observed by the English butler. Evidently, Stevens's insinuation about the vulgarity of the bantering remark targets his employer's violation of a measure of decorum. It is also obvious that the butler is "most troubled by[this] culture of informality and 'bantering' that Mr Farraday seems to expect as part of his service" ( Sloane, 2018, p. 172).

These contradictory attitudes towards bantering are invested by Stevens to expose his American employer's incognizance of the genuine English cultural traits. The emotionally charged phrase of "would never have" emphasizes the gap between the two cultures in question. It is noteworthy that Stevens's denial of implying "anything derogatory" about Mr Farraday's bantering is 
immediately followed by attributing this kind of language to his being "after all, an American gentleman." Mentioning the nationality of Mr Farraday brings to mind different two countries, England and America, with different effects; the former with its set of codes of dealing with butlers, the latter in which these codes are either different or do not even exist. The use of the adjective 'derogatory' implies the negative other-presentation since Mr Farraday does not belong to mainstream English cultural politics of dealing with butlers. Thus the whole bantering incident can be seen as part of the strategy of "negative otherpresentation" performed by one endowed with a sense of cultural superiority.

Alternatively, the American diplomat, Mr Lewis, uses the same "strategy of negative other-presentation and positive self-presentation" to alert his European peers to the emergence of America as a superpower. He is sent by his government to the "unofficial" international conference organized by Lord Darlington as to discuss and revise "the harshest terms of the Versailles treaty" (Ishiguro, 1989, p. 78). van Dijk(1993) explains the semantic aspect of the strategy.

... in general, dominance is semantically signalled by positive selfpresentation and negative other-presentation or derogation. We may expect, therefore, that the various semantic modes of meaning also reflect such an overall strategy, e.g. by concealing negative properties of the own group ... and emphasizing or inventing those of the Others ... (p. 275)

Manipulation of words as to insinuate derogatory meaning about the rival party is a key weapon here. The dominant team establishes two sets of attributes: positive and negative. As van Dijk sees it, not all the negative attributes assigned by the dominant group need to belong to the dominated group; some of these might just be invented as further derogatoriness. This strategy is detected in Mr Lewis's brief speech in which he antagonizes the European delegates, especially the English. The speech goes as follows.

' ... You gentlemen here, forgive me, but you just a bunch of naïve dreamers. And if you didn't insist on meddling in large affairs that affect the globe, you would actually be charming. Let's take our good host here. What is he? He is a gentleman ... A classic English gentleman. Decent, honest, well-meaning. But his lordship here is an amateur' ... 'He is an 
amateur and international affairs today are no longer for gentlemen amateurs. The sooner you here in Europe realize that the better. All you decent, well-meaning gentlemen, let me ask you, have you any idea what sort of place the world is becoming all around you? The days when you could act out of your noble instincts are over. Except of course, you here in Europe don't yet seem to know it. Gentlemen like our good host still believe it's their business to meddle in matters they don't understand ... You here in Europe need professionals to run your affairs. If you don't realize that soon you're headed for disaster.' (Ishiguro, 1989, pp. 106-7)

The American envoy's antagonizing speech represents America's ascendency into power at a time when Europe was on the brink of WWII. His aim here is to inform his European counterparts that they are no longer the major players in the current political scene and that their international diplomacy is out of time and does not tune with the new global situation. To begin with, the informality of Mr Lewis speech does not suit this political event. According to van Dijk (2019),"[d]epending on context, discourses may have a more or less formal style, defined by the selection of words or the structure of sentences" (p. 229). The choice of one style over another is decided by the occasion, so most properly, if discoursers choose otherwise there should be some implicit message to deliver. In addressing the other European delegates to this international conference, Mr Lewis uses the complementary words 'decent', 'honest', 'noble' which evoke principles of chivalry; both systems and codes are relevant to the Middle Ages. Further, he uses the word 'classic,' which means genuine, but it also denotes old times. The American envoy does not draw two specific sets of attributes, positive and negative; rather, he creates a tone that is highly emphatic about the negative attributes of his opponents. He describes them as "amateur" politicians, at the same time he tells them that their policies no longer belong to current political affairs; their policies are old fashioned. Positive selfpresentation is only hinted to as he, toward the end of his speech, implies that his country is professional enough to take the lead in political global affairs. Thus, it is no longer the age of European domination as it is already replaced by American power.

A further strategy, the relativity of knowledge, is used by the American envoy to ascertain his country's global position. Knowledge is shown to be manipulated by him to show the domination of American international diplomacy. van Dijk(2012) clarifies the relativity of knowledge as, "what is 
knowledge for one community may be just mere belief or prejudice or totally ignored by another. Hence also such relativity is also relative, as it should be: for the members of the community itself, knowledge will usually be seen as 'true belief'(as the classical definition in epistemology defines it), and not to be relative at all" (p.153). Knowledge here is categorized as social; it is agreed on and held by members of a certain community. The limited scale of this knowledge endows it with certain standards, also agreed on by members of this particular community, but not necessarily by other communities. This non-universal aspect is mainly what makes this type of knowledge a relative one. van Dijk draws attention to the issue of the strong belief of a community in its social knowledge to the extent that it does not hold it as relative, rather as an un-debatable and well-established knowledge.

A close reading of Mr Lewis's speech shows that he is empowered by the knowledge of his country's emergence as a superpower. The transition of Europe's role, from being the major player into that of a secondary one, is represented in the part played by the issue of knowledge in the American's brief speech. On one hand, the European community of politicians at the conference holds the knowledge of its political domination, which is partly indicated in organizing this private political conference by Lord Darlington. This knowledge is taken for granted by the European community. On the other hand, this same knowledge is doubted, even ridiculed by Mr Lewis, whose views certainly represent those of his country. Such a negative attitude implies America's belief in its political domination and at the same time emphasizes the relativity of Europe's knowledge of its domination. Further, knowledge is classified by van Dijk (2012) as, "general or specific ... general or generic knowledge ... tends to be socially or culturally shared and can be used in many different situations" (p.153). The general political knowledge shared by the Europeans delegates is counteracted by the American envoy. His aim is conveying his country's specific knowledge of the change of the military and political global scene. Indeed, he acts as if he were a teacher giving his students a new lesson, in other words, he turns the banquet given at the end of the conference into a classroom situation where this political lesson is given for the first time. Thus, American domination over the political scene is represented not only by 'ignoring' European general knowledge but also in substituting this 'old' general knowledge by the 'new and specific' one of the American ascendency into power. 
Furthermore, Mr Lewis's speech targets the European delegates' "cognitive" knowledge. Europe's possession of colonies in Africa and Asia empowers its delegates with the cognitive knowledge that they are still masters of the global political situation. Meanwhile, the American envoy is well aware of the fact that his country does not possess colonies but already enjoys a much stronger economic and military position. Peter Sloane (2018) sheds light on this emerging situation by pointing out that America, "in its cultural, military, and economic hegemony figures itself as a kind of overseer, thereby diminishing the agency of the more established but declining nations ... Ironically, of course, Lewis proposes that the colonizers now need colonial overseeing" (p.171). This transitional stage in world politics has not been acknowledged yet by these European politicians, therefore it cannot be considered as part of their cognitive and social knowledge. Here, the speech of the American envoy functions as a disrupter to the old established knowledge of their political domination; an effect which is clear in their reaction as "[t]here was a stunned silence" (Ishiguro, 1989, p. 107). This reaction can also be attributed to the strategy of positive self-presentation and negative other-presentation which, as mentioned earlier, is manipulated by the American envoy to emphasize the domination of his country over the current political scene.

However, years later, after this political conference, Stevens can counteract American demonstration of power with the strategy of manipulating knowledge as to maintain power. The butler demonstrates his power over the American characters by withholding information that they are eager to have. The views of van Dijk (1989) on how discourse relates to power shed light on Stevens's negative response.

Except in the case of bodily force, power of A over B's actual or possible actions presupposes that $\mathrm{A}$ must have control over the cognitive conditions of actions of B, such as desires, wishes, plans, and beliefs. For whatever reasons, B may accept or agree to do as A wishes, or to follow the law, rules, or consensus to act in agreement with (the interests of) A. In other words, social power is usually indirect and operates through the "minds" of people...[P]ower is intentionally or unwittingly exercised by $\mathrm{A}$ in order to maintain or enlarge this power basis of $\mathrm{A}$, or to prevent $\mathrm{B}$ from acquiring it. In other words, the exercise of power by A is usually in A's interest. (p.20) 
By excluding bodily force, van Dijk focuses on mental power which, when exercised, delivers social control. The plan here is that the party that "knows" suppresses its knowledge and deprives the rival party of this desired knowledge. van Dijk (2006) emphasizes this unequal relationship by relating it to manipulation which he defines as, "[A] communicative and interactional practice, in which a manipulator exercises control over other people, usually against their will or against their best interest" (p. 360). Knowledge is the key player in this relationship. By not attaining the desired knowledge, the deprived party falls under the control of the knowing party. In such an unequal relationship, knowledge becomes the key weapon used by the superior party.

Stevens's dealing with one of Mr Farraday's American guests, Mrs. Wakefield, who inquires about the history of an arch in the Darlington Hall, illustrates van Dijk's views on the power of knowledge. The American lady closely examines the piece of architecture and persistently inquires about it, which marks her desire for knowledge about its history and originality. The architectural style of the arch is that of the $17^{\text {th }}$ century. Meanwhile, as Stevens tells us earlier, the Darlington Hall is built in the $18^{\text {th }}$ century and it had remained in the possession of the Darlingtons for two centuries. So, most probably the arch is not genuine, however, Stevens refrains from clarifying its history to the American lady. He gives her evasive replies such as "It is possible, madam" (Ishiguro, 1989, p. 129), and "I'm not sure, madam..." (Ishiguro, 1989, p.129). If he answers her inquiries, he will be providing her with knowledge on the history of Darlington Hall. But he is adamant to do that. Stevens goes further by denying working for Lord Darlington; had he told her the truth about serving the English Lord for about thirty years, Mrs. Wakefield would have asked more questions. Stevens's reaction to the lady's inquiries obstructs her acquisition of knowledge on English cultural heritage. Thus, empowered by this particular knowledge, the butler is considered as having control over the cognitive conditions of the actions of the American lady. The butler is empowered with a knowledge which he manipulates to defend English cultural heritage against American trespass.

According to van Dijk's view on manipulation, Stevens's withholding of knowledge represents an abuse of power -- of knowledge - as this attitude implies, "the exercise of a form of illegitimate influence by means of discourse: manipulators make others believe or do things that are in the interest of the manipulator, and against the best interests of the manipulated ... "(van Dijk, 
2006, p. 360). Stevens is considered by Mr Farraday and his American guest as an authentic source of knowledge, and as an integral part of English culture. But the English butler uses his knowledge in a way that misguides these Americans.

Furthermore, knowing whether the arch is original or fake would decide not only its historical and architectural value but also the material financial value of the whole property. These Americans have paid a fortune in buying English estates seeking to attach themselves to a genuine aspect of English life; here it is an English country house that had once been owned by an Aristocratic family. In a later encounter between Stevens and his American employer, the latter expresses concern over a possible financial loss as well as a social disgrace among his American peers.

'You know, Stevens, Mrs. Wakefield wasn't as impressed with this house as I believe she ought to have been.'

'Is that so, sir?'

'... she seemed to think I was exaggerating the pedigree of this place. That I was making it up about all these features going back centuries.'

'Indeed, sir?'

'She kept asserting everything was "mock" ... She even thought you were "mock" ...'

'Indeed, sir?'

'... I'd told her you were the real thing. A real old English butler. . . But Mrs. Wakefield contradicted me on this point....'

'Is that so, sir?'

'Mrs. Wakefield ... was convinced you never worked here until I hired you ... Made me look pretty much a fool ...'

'It's most regrettable, sir.'

'I mean to say, Stevens, this is a genuine grand old English house, isn't it? That's what I paid for. And you're a genuine old- fashioned English butler ... You're the real thing, aren't you? ... isn't that what I have?'

'I venture to say you do, sir.'

'Then can you explain to me what Mrs. Wakefield is saying? It's a big mystery to me.'

'It is possible I may well have given the lady a slightly misleading picture concerning my career, sir ...'

'I'll say it caused embarrassment. Those people have now got me down for a braggart and a liar ...' 
'I'm very sorry, sir. I had no idea I might cause you such embarrassment.'

'... why did you tell her such a tale?'

I considered the situation for a moment, then said: 'I'm very sorry, sir. But it is to do with the ways of this country.'

'What are you talking about, man?'

'I mean to say, sir, that it is not customary in England for an employer to discuss his past employers.'

'OK, Stevens, so you don't wish to divulge past confidences. But does that extend to you actually denying having worked for anyone other than me?'

'It does seem a little extreme when you put it that way, sir. But it has often been considered desirable for employees to give such an impression ... sir.'

'Well, I only wish I'd known about your custom before, Stevens ... It certainly made me look like a chump.'(Ishiguro, 1989, pp. 130-2)

In the above passage, it can be noticed that Stevens's response to his American employer echoes his response to Mrs. Wakefield when he declines to disclose information on the history of the place and its previous owner. Holding back knowledge about Darlington Hall is also considered, as mentioned earlier, a kind of manipulation. While Mr Farraday is explicit enough about the reason for purchasing Darlington Hall, Stevens's replies remain evasive. His justification for not talking about Lord Darlington as this silence complies with English cultural traits suggests "mental manipulation" (van Dijk, 2006, p. 360). As Mr Farraday tells Stevens, he has purchased the estate for its originality; casting doubts on this originality threatens him a financial loss. But this is not the only loss that faces Farraday as a negative outcome of Stevens's "illegitimate influence." The butler's power abuse has already affected social disgrace for the American employer among his American peers living in England. Hence, his denial of knowledge of the place becomes against the interest of these Americans.

On the other hand, the butler's replies to his American employer indicate his tendency, if not his desire, to keep himself alienated from this employer. The wide gap between Mr Farraday and his former employer, Lord Darlington, affect this detached attitude. For as shown earlier, Stevens strongly believes in the elegance and importance of Lord Darlington for taking part in serving a 
civilization and shaping history. The butler also harbours a strong belief that he has had his own part in shaping history by working for his English Lord. This belief seems to escalate Stevens's resistance to informing his American employer about his serving years of Lord Darlington; hence, his replies are evasive and manipulative of the American's ignorance of butlers' professional life. Indeed, van Dijk (2006) sees the consequence of manipulative discourse as a negative one which "occurs when the recipients are unable to understand the real intentions or to see the full consequences of the beliefs or actions advocated by the manipulator" (p. 361). Ignorance of the recipients plays a crucial part in this situation. Their dependence on what the manipulator provides them with knowledge enhances their vulnerability. This passive position is clear in the encounter between Stevens and his American employer.

Their dialogue, which contains twenty-two turns, shows Mr Farraday's confusion and anxiety at Stevens's denial of his past employment by Lord Darlington. The butler's share of these turns are twelve, four of them are interrogative clauses expressing exclamatory statements. Apparently, Stevens pretends to be moved by Mr Farraday's embarrassment caused by the former's act of denying that he once worked for Lord Darlington. However, putting the butler replies in the context of his sense of cultural superiority over the American employer, it turns out that they suggest the former gratification for his victory over the one he believes to be culturally inferior, hence, his domination. Thus, Stevens's replies which express regret are not to be taken seriously. Further, he tells Mr Farraday that talking about former employers "is not customary in England", which suggests stating a professional fact of English butlers. Nonetheless, Stevens reply envelops his rejection of "the commodification of English heritage for American tourists" (Walkowitz, 2015, p. 112), and this is the effort he exerts to ruin the American's cultural bargain of buying an English estate. The reply also delivers the effect of leaving $\mathrm{Mr}$ Farraday in the dark regarding the butler's motives. This is obvious in his response to Stevens's justification. Mr Farraday shows his ignorance of these English traditions; he also expresses his bewilderment at his lack of such knowledge. Stevens manipulates his position as the sole narrator by revealing that he too busy to "give such matters a great deal of attention" (Ishiguro, 1989, p. 132). Thus, an event that has caused much embarrassment and bewilderment for his employer is simply tossed away by him for its sheer triviality; such haughtiness emphasizes his sense of domination over his American employer. 


\section{Conclusion}

The present study has shown how American ascendency into power in the years preceding and succeeding WWII is combated by an English butler, Stevens, who strongly believes in the greatness of his country. Although he is in a material and social position much inferior to that of his American employer, he uses strategies that assert his domination as an English man over his master. By applying aspects of T. A. van Dijk's Critical Discourse Analysis of Stevens's encounters with his American employer, this study has shown how the former manipulates knowledge as his only weapon of domination over the latter. Examining the encounters between Stevens and his American employer has also shown the butler's insistence on combating what he sees as the Americans' trespassing onto genuine English tradition. The study has also examined how American politicians, represented by Mr Lewis, see themselves both as the supervisors and key players of the political situation. van Dijk's CDA is applied to investigate the political message which the American envoy sends to his European peers to inform them of the new political situation. Knowledge is shown as the weapon both used and abused by the two parties, the English and the American, in their battle for domination.

\section{References}

Ager, Stanley and Fiona St. Aubyn. (1980). The Butler's Guide: To Running the Home and Other Graces. New York: Clarkson Potter.

Atkinson, Rob. (1995). How the Butler Was Made to Do It: The Perverted Professionalism. The Remains of the Day. The Yale Law Journal, 105(1), 177220. Doi: $10.2307 / 797142$.

Bentley, Nick. (2014). 'Who Do You think You Are Kidding?': The Retrieval of the Second World War in Kazuo Ishiguro's The Remains of the Day and Ian McEwan's Atonement. In Elodie Rousselot (Ed.), Exoticizing the Past in Contemporary Neo-Historical Fiction (pp. 138-159). London: Palgrave Macmillan.

Bruce, Alastair. (1980). Forward. In Stanley Ager and Fiona St. Aubyn, The Butler's Guide: To Running the Home and Other Graces (pp. 6-9). New York: Clarkson Potter.

Cohn, Dorrit. (1978). Transparent Minds. Princeton: Princeton UP.

Emara, Maha. (2015). Kazuo Ishiguro's The Remains of the Day: A Historiographical 
Approach. English Language and Literature Studies, 5 (4), 8-20.

URL:http://dx.doi.org/10.5539/ells.v5n4p8.

Ferry, Steven M. (2001, March 9-11).The Indomitable British Butler. Restoring the Art(Conference presentation). Starkey International in Denver, Colorado,USA. www.modernbutlers.com/wp-content/uploads/2011/04/indomitable

Holmberg, Kim et al. (2009). What is Library 2.0? Journal of Documentatio, 65 (4), 668- 681 • DOI: $10.1108 / 00220410910970294$

Horton, Emily. (2014). Contemporary Crisis Fiction. New York: Palgrave Macmillan.

Ishiguro Kazuo. (1989). The Remains of the Day. London: Faber and Faber.

Marcus, Amit. (2006). Kazuo Ishiguro's The Remains of the Day: The Discourse of Self-Deception. Partial Answers: Journal of Literature and the History of Ideas, 4(1), 129-150. DOI: 10.1353/pan.0.0046.

Rich, Kelly, M. (2016). Troubling Humanities: Literary Jurisprudence and Crimes against Humanity in Ishiguro's Remains of the Day and McEwan's Atonement. Culture and the Humanities, 12(3), 496-508. DOI: $10.1177 / 1743872114541520$

Rushdie, Salman. (2017, August 17). Re-reading The Remains of the Day by Kazou Ishiguro. The Guardian. https://www.theguardian.com/books/2012/aug/17/rereading-remains-daysalman- rushdie.

Sloane, Peter. (2018). Literature of Resistance under U. S. "cultural siege": Kazou Ishiguro's narratives of occupation. Critique, 59(2), 154-167. DOI: $\underline{10.1080 / 00111619.2017 .1375456}$

Swift, Graham. (2008). Shorts: Kazuo Ishiguro. In Brian W. Shaffer and Cynthia F. Wong (Eds.), Conversations with Kazuo Ishiguro (pp.35-14). Jackson: University Press of Mississippi.

van Dijk, Teun A. (1989). Structures of Discourse and Structure of Power. Annals of International Communication Association, 12 (1), 18-59. https://doi.org/10.1080/23808985.1989.11678711

van Dijk, Teun A. (1993). Principles of Critical Discourse Analysis. Discourse and Society, 4(2), 249-283. https://doi.org/10.1177/0957926593004002006 
van Dijk, Teun A. (2001). Critical Discourse Analysis. In Deborah Schiffrin et al. (Eds.), The Handbook of Discourse Analysis (pp.352 - 351). Oxford: Blackwell.

van Dijk, Teun A. (2006). Discourse and Manipulation. Discourse and Society, 17 (2), 359-383. https://doi.org/10.1177/0957926506060250

van Dijk, Teun A. (2012). Knowledge, Discourse and Domination. In Michael Meeuwis and Jan-Ola Ostman (Eds.), Pragmaticizing Understanding (pp.151196). Amsterdam: John Benjamins.

van Dijk, Teun A. (2018). Discourse and Migration. In Ricard Zapata-Barrero and Evren Yalaz (Eds.), Qualitative Research in European Migration Studies (pp.227-245). Cham: Springer Open.

Walkowitz, Rebecca L. (2015). Born Translated: The Contemporary Novel in an Age of World Literature. New York: Colombia University Press.

Whitely, Sara. (2011). Text World Theory, real readers and emotional response to The Remains of the Day. Language and Literature 20(1), 23-42. DOI: $\underline{10.1177 / 0963947010377950}$

Wong, Cynthia F. (2008). Like Idealism is to the Intellect: An Interview with Kazuo Ishiguro. In Brian W. Shaffer and Cynthia F. Wong (Eds.), Conversations with Kazuo Ishiguro (pp. 174-188). Jackson: University Press of Mississippi. 